\title{
evolução do setor ervateiro durante o século XIX: uma análise dos avanços tecnológicos na cadeia produtiva*
}

\section{the evolution of the yerba-mate sector in the 19th century: an analysis of the tecnological advances in the productive chain}

\author{
Lilian da Rosa $\star \star$ \\ Instituto de Economia, Universidade Estadual de Campinas, Campinas, São Paulo, Brasil \\ Taciana Santos de Souza $\star \star \star$ \\ Instituto de Economia, Universidade Estadual de Campinas, Campinas, São Paulo, Brasil
}

\section{RESUMO}

Este trabalho analisa a trajetória do setor ervateiro nas províncias sulistas do Brasil, durante os anos de 1822 a 1889. Para analisar a evolução das transformações de uma atividade artesanal para uma atividade industrial, este artigo propõe uma abordagem da história econômica apoiada em teorias de microeconomia. Para isso, o estudo apontou uma divisão da estruturação desse setor de acordo com as mudanças ocorridas na cadeia produtiva do mate e identificou as implicações de cada fase para a qualidade e a quantidade da produção, o tipo de mão de obra empregada e as estratégias comerciais adotadas pelos produtores. Ao final, constatou-se que a implementação de inovações na atividade do mate na Província do Paraná, apoiada em investimentos públicos e privados, alavancou a produção na região, contribuindo para o desenvolvimento desse ramo e da economia local.

Palavras-chave: Erva-mate. Império. Paradigmas tecnológicos.

\section{Abstract}

This work addresses the trajectory of the yerba-mate sector in the southern provinces of Brazil, over the years 1822 to 1889 . To analyze the evolution of the changes from a handmade production to an industrial manufacturing, this paper proposes an approach to economic history supported by microeconomic theories. For this purpose, this work pointed out an organizational sector division - according to the changes occurred in the mate's production chain - and identified the implications of each phase for the qualitative and quantitative aspects of the production, the sort of the labor employed and the commercial strategies adopted by producers. At the end, we concluded that the implementation of innovations in the mate's activity in the Province of Paraná, supported by public and private investments, increased the production in this region, contributing to the development of this segment and the local economy.

Keywords: Yerba-mate. Empire of Brazil. Technological paradigms.

* As autoras agradecem à CAPES e FAPESP (Processo n. 2013/08.503) pelo financiamento. Também agradecemos a Ligia Maria Osório Silva e Ana Lucia Gonçalves da Silva pelas contribuições teóricas.

Submetido: 28 de julho de 2017; aceito: 19 de janeiro de 2019.

$\star \star$ Doutoranda e mestre em Desenvolvimento Econômico pelo Instituto de Economia da Universidade Estadual de Campinas.E-mail: lilianrosa.rs@gmail.com

$\star \star \star$ Doutoranda e mestre em Desenvolvimento Econômico pelo Instituto de Economia da Universidade Estadual de Campinas.E-mail: tacianass@gmail.com 


\section{Introdução}

No Sul do Brasil, a árvore do mate, Ilex paraguariensis, é tradicionalmente utilizada para preparar o chimarrão. Essa árvore, da qual são extraídos os galhos e as folhas para a produção de erva-mate - produto triturado que chega de fato ao consumidor -, é originária de clima temperado úmido ou subtropical úmido (Carvalho, 2003) e é encontrada principalmente em meio às florestas de araucária, regiões compostas por solo basáltico, avermelhado e argiloso (Oliveira; Rotta, 1985). Essas características contribuíram para determinar a fronteira geográfica de sua proliferação e possibilitaram que a erva-mate, ao longo do século XIX, despontasse como um importante produto socioeconômico para as províncias localizadas na porção meridional do território: Santa Catarina, São Pedro do Rio Grande do Sul e Quinta Comarca de São Paulo - essa última se emancipou em 1853 e se tornou a Província do Paraná.

Atualmente, a erva-mate possui um significativo valor cultural e econômico para os habitantes dos estados da região Sul e do estado de Mato Grosso do Sul ${ }^{1}$. Nota-se essa importância devido à sua alusão em diferentes símbolos oficiais. Como exemplo, com o Decreto-Lei n. 2.457 de 31 de março de 1947, ela recebeu uma menção na bandeira do Paraná, que teve a inserção de um ramo da árvore do mate para circunscrever parcialmente o lado esquerdo da esfera central (Bandeira do Paraná). De forma similar, ela recebeu uma menção no brasão de arma de Mato Grosso do Sul, com o Decreto n. 2 de 1ㅇ de janeiro de 1979, que sancionou a inclusão de um ramo da mesma árvore para adornar a parte direita do referido emblema. No Rio Grande do Sul, a Lei n. 7.439 de 8 de dezembro de 1980 transformou a árvore do mate em um símbolo do estado, enquanto a Lei n. 11.929 de 20 de junho de 2003 tornou o chimarrão a bebida oficial (Ucha, 2012).

Além dessas reconhecidas formalizações, a árvore do mate tem uma importância como matéria-prima para a fabricação de outros produtos alimentícios - como chá-mate, cervejas (Dado Bier e Mier Bier), bolos, sorvetes e massas - e também de produtos cosméticos - como xampus, sabonetes e hidratantes - geralmente produzidos a partir da sua seiva.

1 Este trabalho não trata sobre a produção ervateira de Mato Grosso, pois esta despontou como atividade econômica somente próximo do término do recorte temporal proposto. 
Figura 1 - Área de distribuição de erva-mate

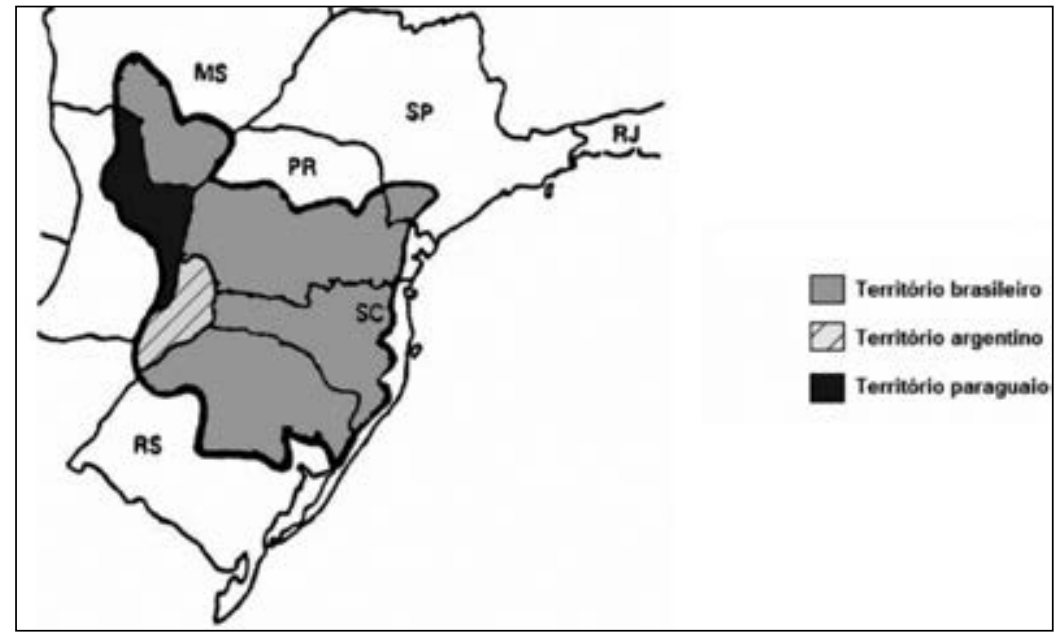

Fonte: Hoszczaruk (2015), adaptado de Oliveira; Rotta (1985).

Para atender a essa demanda, o Brasil gerou, em 2014, cerca de 603 mil toneladas de erva triturada (IBGE, 2013), volume que abasteceu tanto o mercado nacional quanto o internacional. O produto é exportado de várias maneiras para mais de 30 países. Em 2016, o setor ervateiro brasileiro gerou aproximadamente 102 milhões de dólares (COMEX, 2015). De certa forma, parte da importância econômica, social e cultural que a erva-mate ostenta nos dias de hoje também se deve ao seu valor enquanto objeto histórico, em particular desde os primeiros indícios de estruturação do setor ervateiro, ocorridos nos tempos em que o Brasil ainda era Império.

De modo geral, remontando ao século XIX, a economia do complexo ervateiro contribuiu para a colonização em áreas com concentrações de ervais nativos, em propriedade privadas ou mesmo em terras devolutas. Isso porque a colheita do mate era uma atividade extrativista e sazonal que exigia um significativo contingente de coletores, os quais, com o passar do tempo, estabeleceram-se lentamente nos lugares onde trabalhavam. Esse assentamento recorrente, de certa forma, contribuiu com a formação e o desenvolvimento de muitos dos atuais municípios dessas regiões, como Morretes, Paranaguá e Curitiba (PR), Mafra, Canoinhas e Joinville (SC), Cruz Alta, Passo Fundo e Palmeira das Missões (RS) - ver Figura 1. Além disso, a sua extração, fabricação e comercialização 
possibilitaram que uma parcela da população pobre participasse de um mercado relativamente emergente. Esses pequenos extratores vendiam sua força de trabalho aos grandes ervateiros ou trabalhavam por conta própria nos ervais públicos, de modo que, após a fabricação, repassavam essa erva aos comerciantes locais, pois normalmente a trocavam por utensílios e ferramentas de trabalho. Nesse sentido, a erva-mate também desempenhava o papel de uma espécie de moeda de troca para esses mercados regionais (Rosa, 2015).

O hábito de tomar chimarrão em alguns países da América Independente corroborou a afirmação e a consolidação desse setor no Brasil. Isso porque boa parte das relações comerciais com esses países se estabeleceu em torno da erva-mate. Ela era exportada principalmente para o Uruguai, o Chile, a Bolívia e a Argentina (Rosa, 2015), de tal forma que se destacava entre os oito produtos mais comercializados pelo Império brasileiro (Soares, 1977), o que sugere a relevância dela para as províncias sulistas, uma vez que estas eram as principais regiões produtoras. Nos Oitocentos, houve períodos em que esse comércio se intensificou devido a motivações políticas internacionais. O Paraguai, único concorrente do Brasil na época, num primeiro ínterim, passou por um longo isolamento com o comando de Francia (1814-1840) e só retomou suas relações diplomáticas e comerciais, posteriormente, com o governo de Carlos Antônio Lopes (1840-1862). Embora tais relações tenham se fortalecido no início do governo de Francisco Solano Lopes (18621870), num segundo ínterim, com a eclosão da Guerra do Paraguai, novamente as fronteiras comerciais foram fechadas (Doratioto, 2002), o que tornava o Brasil ${ }^{2}$ a única nação com condições para produzir e exportar a erva-mate.

Assim, o quadro histórico até aqui exposto sugere a necessidade de analisar como ocorreu a emergência e a trajetória desse setor que passou por várias transformações ao deixar de ser uma atividade artesanal até se tornar uma atividade industrial, especialmente no final do século XIX. Essas mudanças instigam a realização de uma pesquisa de história econômica apoiada em teorias de microeconomia, uma vez que muitas das implementações na atividade produtiva ocorridas no setor ervateiro

2 Ressalta-se que, nessa época, a Argentina ainda não havia descoberto nem mesmo plantado seus próprios ervais. 
oitocentista perduram até os dias atuais. Nesse sentido, este estudo tem como objetivo avaliar a evolução desse ramo produtivo, ao longo do período de 1822-1889, no que concerne à estruturação da cadeia produtiva de cada fase, bem como avaliar as suas implicações para a qualidade e a quantidade da produção, o tipo de mão de obra empregada, as estratégias comerciais adotadas pelos ervateiros, entre outros aspectos.

Em vista desse propósito, o presente artigo está dividido em cinco partes, além desta introdução e da conclusão. A primeira é destinada aos procedimentos metodológicos e às teorias utilizadas nessa pesquisa. A segunda revisita o início da produção do mate, caracterizada por procedimentos artesanais, além de revisar a bibliografia acerca do tema. A terceira parte se destina ao "ciclo dos engenhos hidráulicos" e a quarta, ao "ciclo dos engenhos a vapor". Ambos os ciclos discutem as contribuições que as respectivas tecnologias tiveram para o aumento da qualidade e da quantidade de erva-mate produzida, bem como as transformações em seu processo produtivo. A quinta parte aborda os principais aspectos socioeconômicos sobre as transformações ocorridas, principalmente, na segunda metade dos Oitocentos.

\section{Destruição criadora, estratégias de concorrência e paradigmas tecnológicos}

A partir da segunda metade do século XVIII, devido também ao processo desencadeado pela revolução industrial, os Estados nacionais, as colônias e as semicolônias estabeleceram novas formas de relações comerciais, baseadas na exportação de produtos manufaturados, na importação de matérias-primas e nas transações financeiras (Hobsbawm, 1986). Isso possibilitou que diferentes regiões - cada qual especializada em seu ramo produtivo - comercializassem entre si. Essas transações suscitaram mudanças no modo de vida e no desenvolvimento das forças produtivas, especialmente das economias nascentes. Cada região emergiu com suas especificidades e em seu próprio tempo histórico, de acordo com sua capacidade de inovar ou mesmo de implantar paradigmas tecnológicos já existentes em outros países detentores desse conhecimento. De certo modo, esse processo é observado na formação dos Estados nacionais, como foi o caso do Império brasileiro, mais especificamente 
o das províncias sulistas, já que os setores produtivos geralmente copiavam e disseminavam o desenvolvimento tecnológico (algumas vezes com melhoramentos) originário da Inglaterra, da Alemanha e do Paraguai. Ao analisar a trajetória do setor ervateiro, portanto, este artigo também se propõe a esmiuçar um pouco dessas facetas.

Esse processo de emergência e de subsequente manutenção de um ramo econômico está relacionado ao dinamismo desse setor e à capacidade dele em produzir, reinventar-se e competir com seus concorrentes dentro de uma lógica de mercado. Assim, para se manter sempre atuante e não se tornar obsoleto, o aparato produtivo que busca a inovação incorpora uma potente vantagem competitiva. Com relação a isso, Schumpeter qualificou esse processo a partir de diferentes modos, que tratam de insumos, recursos naturais, produção, organização, comercialização e mercados consumidores. Essas inovações, bem como as imitações introduzidas em velhas formas de produção, são estratégias adotadas para superar concorrentes. Nesse sentido, essa percepção dinâmica do espaço econômico revela o processo da permanente "destruição criadora", no qual o novo e o velho podem coexistir, mas são constantemente modificados, transformados, destruídos e criados (Schumpeter, 1984). Schumpeter também discutiu como as empresas adotam práticas ativas e passivas como estratégias para a concorrência. As práticas ativas são as que priorizam a inovação, via investimento tecnológico e lançamento de produtos novos, por exemplo, enquanto as práticas passivas são as que visam à defesa da posição de cada aparelho produtivo, via patentes ou contratos (Schumpeter, 1984). Ambas, ao mesmo tempo que protegem ou alavancam uma determinada empresa, igualmente interferem em todo o ramo, já que criam, muitas vezes, barreiras à entrada para novos concorrentes (Porter, 1986).

A perspectiva de observar o setor produtivo, ao longo da história, a partir da inovação, é um método dinâmico de análise da economia. Por isso, esta pesquisa não se propõe a mensurar valores sobre os custos e os preços de erva-mate, mas reforça o impacto das inovações no ramo ervateiro, como uma estratégia de acumulação de vantagens competitivas e de acumulação de lucro.

Outra abordagem heterodoxa, que se incorpora na base metodológica deste trabalho, é a análise de Possas (1990), sumariamente conhecida como teoria da "estrutura-conduta-desempenho". Ela advoga que 
é possível identificar como a estrutura de um setor interfere diretamente na conduta das empresas desse setor que, por sua vez, conduz estratégias que determinarão o desempenho não só das empresas, mas também do ramo como um todo. Assim, os aspectos estruturais são determinados por condições do mercado (exógenas) e por condições técnicas (endógenas). Essas condições técnicas são criadas pelas empresas do setor e possibilitam economias de escala e vantagens competitivas. As condições do mercado, por sua vez, têm mais relação com aspectos exteriores à empresa, como da demanda ou da própria difusão de inovações.

Embora parte desses aspectos estruturais sejam tratados como endógenos, deve-se salientar que muitas dessas condições técnicas, especialmente quando se trata de países com maior subordinação ou dependência econômica e política, estão submetidas à disponibilidade de uma gama de conhecimentos e de tecnologias denominadas por Dosi (2006) como "paradigmas tecnológicos". A destruição, a criação, a difusão e a implantação de diferentes processos de produção compõem o que se denomina como "trajetória tecnológica" (Dosi, 2006). Isso, geralmente, envolve uma sequência de transformações na busca por inovações, conhecimentos e alterações nos métodos de produção, bem como por fontes de investimento que podem englobar as esferas pública e privada (Silva, 2010). Desse modo, as interações entre as empresas e as competições nos setores formam assimetrias que podem ser modificadas com o tempo dados os limites traçados pelas "fronteiras tecnológicas" (Dosi, 2006), que vão muito além dos espaços geográficos, pois tratam dos processos de dominação e de subordinação que o capital impõe a determinados povos ou regiões. Essas fronteiras tecnológicas estão diretamente associadas à capacidade e à autonomia dos Estados em investirem e determinarem novas técnicas e formas de produção. Além disso, ainda sob essa perspectiva de transformações na busca por inovações, as mudanças industriais e tecnológicas podem ser observadas tanto por alterações na trajetória produtiva do setor, quanto por alterações nas relações com o meio, pois entende-se que o "o sistema econômico constitui um ambiente complexo, pelo qual a mudança e a transformação provêm da interação das suas partes constituintes, e de variáveis parcialmente exógenas" (Dosi, 2006, p. 22).

Essas teorias propostas por Schumpeter, Dosi e Possas podem auxiliar a análise e a discussão das transformações que originaram e consolidaram 
o setor ervateiro oitocentista. Dentro dessa perspectiva, nas seções seguintes, pretende-se identificar as cadeias produtivas de erva-mate, desde os insumos até a distribuição final, com a finalidade de compreender as alterações estruturais e tecnológicas desse setor, ou seja, de elucidar as mudanças nas formas de divisão e organização do trabalho, na inovação de processos e produtos e no uso de insumos, tecnologias e técnicas de distribuição e comercialização (Dantas; Kertanetzky; Prochnik, 2002). Como consequência dessa opção metodológica, distinguem-se três períodos de produção para o setor ervateiro, os quais, se tratados sequencialmente, constituem a sua trajetória durante o século XIX. O primeiro deles corresponde a uma fase de produção artesanal, ainda rudimentar e não caracterizada pelas teorias microeconômicas mencionadas há pouco; enquanto os dois seguintes, a fase dos engenhos hidráulicos e a fase dos engenhos a vapor, são de fato tratadas como ciclos de produção.

A ideia de seccionar a trajetória do setor ervateiro em diferentes períodos de produção, segundo critérios de inovação,já foi empregada por Temístocles Linhares na obra História econômica do mate, mas sem o enfoque empregado aqui pela microeconomia. Segundo esse autor, ao longo dos Oitocentos, os principais movimentos de inovação tecnológica desse setor ocorreram em três ciclos. O primeiro deles teve início no período colonial e perdurou até meados de 1820 . Nele, a atividade ervateira, exercida basicamente para consumo interno, era realizada de forma artesanal por pobres, indígenas e escravos. Já o segundo ciclo durou de 1820 até 1870 . Esse momento histórico foi marcado principalmente pela ocorrência de melhoramentos tecnológicos, trazidos do Paraguai por dom Francisco Alzagaray e implantados nos engenhos da região de Paranaguá. Em menor grau, o autor também apontou a introdução da força hidráulica como outra mudança importante durante esse ciclo. Por fim, o terceiro deles, de 1870 a 1930, caracterizou-se pela introdução de engenhos a vapor e pela construção de ferrovias (Linhares, 1969).

Para o presente estudo, esse mesmo recorte temporal foi mantido. Contudo, o que Linhares apontou como o primeiro ciclo preferiu-se denominar período de produção artesanal e o que ele apontou como o segundo e o terceiro ciclos preferiu-se denominar primeiro e segundo ciclos por motivos que ficarão mais claros adiante. Outra mudança em relação à obra de Linhares é que aqui foram propostos novos marcos de rupturas e de emergências para explicar as transições entre esses perío- 
dos. Com essas diferenças em vista, a próxima seção aborda a produção artesanal.

\section{Período de produção artesanal}

Nesse primeiro período de produção ervateira, as técnicas de preparação eram consideradas, para os padrões atuais, rudimentares. As ferramentas de trabalho eram basicamente manuais: facões, machados, soques, entre outras. A produção artesanal iniciava pela abertura do acampamento, ou seja, em meio à mata na qual era realizada a colheita, ocorria a fixação e a organização de moradias provisórias e de estruturas de preparação de erva-mate. Dirigiam-se para os ervais muitos homens com carretas ou burros e, assim que chegavam, construíam ranchos para se instalar por semanas ou mesmo por meses, já que muitas vezes o erval se distanciava até 30 léguas da morada de origem (Avé-Lallemant, 1980a). Normalmente, o assentamento era montado em um local onde convergiam as picadas, de modo que facilitava o deslocamento dos animais e das pessoas.

Após a abertura do acampamento, tinha início a poda (ou colheita), que consistia no corte dos galhos e das folhas. Esse trabalho requeria que a árvore fosse escalada e subsequentemente desgalhada. Para isso, o facão era o principal instrumento de auxílio do ervateiro. Depois da poda, realizava-se o sapeco, procedimento pelo qual a ramagem era passada rapidamente sobre a chama de uma fogueira, com o objetivo de secar as folhas e as ramas, desidratando-as. Isso evitava a fermentação e garantia a qualidade do sabor e da tonalidade. Para a continuação da secagem, havia ainda uma etapa seguinte, o carijo, em que uma estrutura de aproximadamente 1,20 $\mathrm{m}$ de altura, feita de achas de pinho (espécie de conífera), era rusticamente construída para formar uma grade de varas fincada no chão através de esteios. Sobre a grade, as folhas e as ramas sapecadas eram dispostas de forma que essas últimas ficassem acima das primeiras e, com brasas embaixo, ambas eram mantidas em temperatura estável, por volta de sete a oito dias, o que garantia a sua torrefação uniforme. Esse procedimento exigia constante vigilância: fogo demais, elas contraíam o gosto da fumaça; fogo de menos, elas não secavam direito. $\mathrm{Na}$ sequência, as folhas e as ramas oriundas do carijo eram introduzidas 
em sacos de couro e depois malhadas com auxílio de um pedaço de madeira ou eram colocadas em um pilão de soque manual. Assim ocorria a trituração e, então, o produto final era empacotado em surrões, uma espécie de saco de couro que assegurava a qualidade durante o transporte, o qual era realizado através de carroças puxadas por burros, cavalos ou bois (Saint-Hilaire, 2002). Todos esses procedimentos descritos, sintetizados na Figura 2, eram normalmente realizados por mão de obra escrava, por índios ou, ainda, por uma parcela da população pobre.

Figura 2 - Etapas da produção artesanal de erva-mate

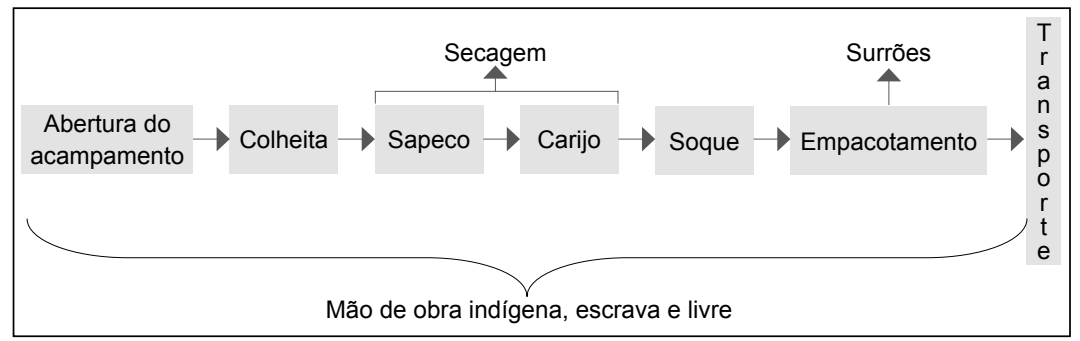

Conforme a descrição anterior, esse período de produção artesanal aparenta ser simplório se comparado com os tempos vindouros, nos quais as formas de produção são um pouco mais condizentes com a ideia de industrialização moderna. De certa forma, Linhares também reconheceu as limitações nos meios de preparação de erva-mate, observadas até 1820, ao dizer que tais "processos de industrialização [...] teriam sido os mais rudimentares e acanhados" (Linhares, 1969, p. 169). Apesar disso, o referido autor caracterizou esse período como um ciclo, sem explicitar o motivo dessa escolha.

O termo ciclo é recorrente na historiografia brasileira. No entanto, ele pode estar associado a diferentes teorias. Roberto Simonsen (1957), por exemplo, defendeu que a economia do Brasil se desenvolveu por meio de uma sucessão de ciclos econômicos: o do pau-brasil, o do açúcar, o da mineração e o do café. Para ele, as ascensões de cada um desses gêneros correspondiam, necessariamente, ao declínio do ciclo pretérito. Mais tarde, autores como Caio Prado Júnior (1942) e Celso Furtado (1959) reinterpretaram a história do Brasil e defenderam que, na verdade, tudo o que ocorria na colônia era consequência de seu perfil primário- 
-exportador, para atender às demandas advindas do comércio metropolitano.

Nesse sentido, a produção artesanal de erva-mate está em desacordo com esses critérios e, portanto, não pode ser compreendida como tal. No presente trabalho, "ciclo" representa um intervalo de tempo em que ocorre algum tipo de mudança no processo de modernização, nas relações de produção, no suprimento de divisas estrangeiras e na ascensão e na posterior superação de algum aspecto do setor em questão. De certa forma, o caráter cíclico desses períodos são as reinvenções e inovações produtivas. Desse modo, o primeiro ciclo de produção se constituiu, de fato, com a inserção de pilões de ferro nos engenhos hidráulicos, que será abordado na seção seguinte.

\section{Primeiro ciclo: engenhos hidráulicos com pilões de ferro}

A chegada da família real ao Brasil, em 1808, contribuiu para uma série de mudanças na então colônia. Somada à já existente, a transferência da burocracia civil e militar da Coroa propiciou a montagem de um corpo burocrático mais amplo e diversificado, o que colaborou para a centralização do poder. Além disso, a Coroa também realizou uma série de modificações no aparelho creditício e fiscal (criação do Banco do Brasil, aumento dos gastos públicos, modificações no sistema tributário), criou uma Junta de Comércio e sancionou a abertura dos portos. De modo geral, todos esses elementos contribuíram para o crescimento urbano, para o aumento dos lucros internos e para a dinamização da base produtiva e econômica (Santos, 1985).

Após a Independência do Brasil em 1822, ocorreram novas transformações, já que a constituição do novo Estado nacional estimulou a composição de todo um conjunto de relações diplomáticas e comerciais próprias. Nesse período, por exemplo, o câmbio se tornou um importante instrumento entre o mercado mundial e a acumulação interna, e o sistema monetário passou a ser regulado conforme os interesses do Império (Santos, 1985). Além disso, pouco a pouco, ocorreu um aprofundamento nas transformações socioeconômicas, que se consolidaram a partir de 1850, com a adoção da Lei Eusébio de Queirós e a sanção 
da Lei de Terras, que engendraram profundas transformações na propriedade da terra e na divisão internacional do trabalho (Silva, 2008). De modo geral, todos os elementos desse breve quadro histórico contribuíram para que os lucros econômicos se solidificassem e fossem investidos no Brasil e, por conseguinte, colaboraram para a formação de uma nova classe empresarial que reinvestia seus excedentes produtivos em diversos setores econômicos. Essa realocação de capitais, por sua vez, suscitou, ao longo do tempo, desenvolvimentos regionais até então inéditos. De certo modo, os ciclos de produção de erva-mate estão atrelados a essa conjuntura política, social e econômica. O primeiro ciclo, por sua vez, inicia justamente a partir de partir 1820, possivelmente, já reflexo das políticas implantadas pela corte portuguesa.

Nesse primeiro ciclo de produção, algumas das etapas de processamento de erva-mate permaneceram idênticas àquelas do período de produção artesanal, enquanto outras foram modificadas ou até mesmo substituídas. Do ponto de vista procedimental, o acampamento, a colheita e o sapeco continuaram praticamente inalterados. Apesar disso, aparentemente os meses nos quais ocorriam essas etapas passaram a ser entre março a agosto, época do ano em que as temperaturas mais baixas retardavam a proliferação da seiva. Provavelmente isso impedia que as folhas e as ramas recém-extraídas estragassem antes de receberem a primeira etapa de secagem (sapeco). De acordo com o relato de um viajante, esse conhecimento foi copiado do Paraguai (Saint-Hilaire, 1978). Tal aprendizado pode ter ajudado a melhorar a produtividade de erva-mate, uma vez que a nova prática contribuía para reduzir as perdas de matéria-prima frequentes em meses mais quentes.

A despeito disso, mudanças mais impactantes ocorreram durante o procedimento de secagem, que recebeu armações mais elaboradas para esse fim. A estrutura do carijo foi substituída por outra, o barbaquá, que denominou a nova etapa. Originalmente, esse novo processo de remoção de umidade - implantado primeiramente no Paraná e posteriormente nas demais províncias sulistas - também foi um conhecimento adquirido do Paraguai. Um registro de época descreve a sua estrutura geral e como o processo de secagem acontecia: o barbaquá era uma espécie de caramanchão armado, em meio à mata, constituído por dois troncos de árvores, com aproximadamente $25 \mathrm{~cm}$ de diâmetro, que eram fincados no chão a uma distância de $2 \mathrm{~m}$ entre si; em cada um dos troncos era 
anexada uma forquilha a uma altura de mais ou menos $2,5 \mathrm{~m}$; sobre as duas forquilhas, era apoiada uma vara flexível, que formava um arco mestre; esse arco era o responsável por sustentar outros cinco arcos menores (igualmente varas flexíveis), cujas extremidades atingiam o chão; entre estes eram trançadas varas transversais (ainda menores) com pequenos intervalos umas das outras, sem que o emaranhado tocasse o solo. O resultado final era uma cobertura arredondada, com cerca de 6 passos de diâmetro e aberta nas extremidades onde se estendiam as forquilhas (Saint-Hilaire, 1978).

Com essa estruturada armada, o processo de secagem ocorria da seguinte forma: após terminado o sapeco, a armação do barbaquá era inteiramente revestida com as folhas e as ramas, de modo que não ficassem espaços vazios entre as varas transversais; em seguida, era aceso um fogo com lenhas verdes, bem no centro da área coberta; depois de aproximadamente "uma hora e meia" expostas ao calor, as folhas e as ramas secavam completamente; na sequência, eram removidas do barbaquá e empilhadas para que, posteriormente, passassem pelos processos de trituração (Saint-Hilaire, 1978). Se comparado ao carijo, que consistia de uma grade suspensa e de laterais completamente abertas, o barbaquá apresentava uma cobertura trançada parcialmente fechada em dois lados. Essa nova estrutura conservava melhor o calor, reduzia a geração de fumaça e ainda secava as ramagens em menor tempo. Não é surpresa que esses atributos o tornaram popular entre os ervateiros. Ainda assim, é importante salientar que provavelmente o registro de Saint-Hilaire, em relação ao tempo de secagem (em torno de uma hora e meia), esteja equivocado. Em todas as outras referências encontradas, esse tempo se mostra sempre mais duradouro. Além disso, mesmo nos melhores secadores mecânicos utilizados atualmente, esse procedimento leva cerca de três horas (Vieira, 2009).

Aos poucos, o barbaquá paraguaio sofreu adaptações e melhorias nas províncias sulistas. Ao final, tornou-se uma construção de madeira (estaleiro), coberta e cercada por todos os lados, que protegia das intempéries as folhas e a ramas oriundas do sapeco e diminuía a dissipação rápida do calor. Outra vantagem é que o acondicionamento em trilhos suspensos na parte interna do estaleiro não expunha as plantas mais diretamente à ação da fumaça. $\mathrm{O}$ fogo era produzido em uma espécie de buraco no chão, longe da construção de madeira, e o calor chegava até elas por 
meio de um canal subterrâneo que possuía entre $10 \mathrm{~m}$ a $20 \mathrm{~m}$ de comprimento. Com esse novo arranjo, o tempo de secagem reduziu para 20 horas, um decréscimo considerável que permitiu aumentar a quantidade de produção para até 50 arrobas diárias (Linhares, 1969).

Após a etapa do barbaquá, a ramagem seca passava por um primeiro processo de trituração, ainda em meio à mata, com auxílio de pilões de madeira. Isso dava origem a fragmentos grosseiros que, na sequência, eram peneirados para separar os pedregulhos e as demais substâncias indesejadas. Ao final desse procedimento, o produto resultante recebia o nome de erva cancheada. A Figura 3 apresenta essa primeira fase da cadeia produtiva, denominada cancheamento. Eckert (2011) afirma que, embora não estivesse totalmente pronta para o consumidor final, essa erva já era uma mercadoria comercializada no mercado externo. Seus compradores, ervateiros e comerciantes estrangeiros, passavam-na por processos de produção adicionais (nova moagem, mistura, empacotamento etc.) e, com isso, agregavam mais valor ao produto. Esse comércio precoce representava certa falta de controle sobre a rede distributiva e inviabilizava a entrada de mais divisas. Contudo, esse ponto de vista não é consenso entre os estudiosos sobre o tema. Autores como Pereira (1996) defendem que o setor ervateiro criou uma burguesia mercantil, que aos poucos dominou toda a cadeia produtiva do mate. As casas de soque ou engenhos adquiriam a erva cancheada de pequenos produtores e na sequência realizavam o restante do processo de produção - o beneficiamento, o empacotamento e o comércio externo. Parte dos dividendos adquiridos nesse comércio teria sido reinvestida no próprio setor ervateiro. Isso, por conseguinte, contribuiu para que, em cerca de 50 anos, emergisse um parque fabril complexo.

Figura 3 - Primeira fase da cadeia produtiva de erva-mate no ciclo dos engenhos hidráulicos

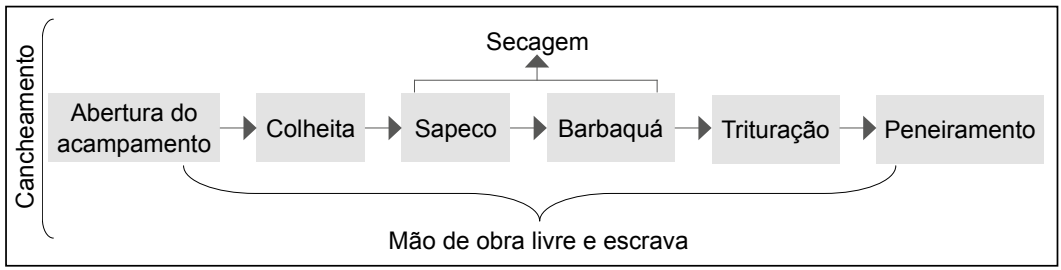


Quando não destinada diretamente ao comércio, a erva cancheada era transportada, com auxílio de bois, carroças e burros, até outro local e era submetida a uma segunda etapa de trituração para o refinamento do produto com o uso de um monjolo ou de um moinho d'água, esse último também conhecido como engenho (Linhares, 1969). De acordo com o relato de um viajante alemão, o monjolo, "uma máquina brasileira", um tipo de triturador que substituía o moinho alemão, é descrito por ser uma estrutura com dois postes de aproximadamente $1 \mathrm{~m}$ fincados no chão, os quais sustentavam uma alavanca que, em uma de suas extremidades, possuía um pilão feito de madeira rígida, que servia para moer, e, na outra extremidade, possuía uma gamela. Esta, por sua vez, recebia água via um canal e, quando enchia, deslocava-se em direção ao solo, o que erguia o outro lado da alavanca. Ao baixar, a gamela despejava a água e, com isso, o pilão caía com toda a força sobre uma selha de madeira, local onde era posta a erva cancheada para triturar (Beschoren, 1989).

O engenho hidráulico, por outro lado, consistia de uma roda d'água que captava a energia de correntezas de rios e riachos e a transferia para moendas ou pilões. Essa roda normalmente era construída com madeira resistente e seu mecanismo podia funcionar de duas maneiras distintas: através de impulsão sub ou sobre axial. Nos engenhos do primeiro tipo (a maioria deles), a água, primeiramente represada e canalizada, atingia por cima a roda, o que geralmente dava mais força e velocidade para os trituradores. Já, nos engenhos do segundo tipo, a água atingia por baixo a roda, o que comumente demandava um maior volume hídrico e, portanto, não os tornavam tão eficientes (Lima, 1983). Ambos foram difundidos principalmente nas regiões que possuíam condições geográficas favoráveis à sua instalação: os terrenos íngremes que margeassem rios ou riachos de águas abundantes e rápidas. Afinal, isso era, para os padrões da época, o que eficientemente movia a roda d'água (Andrade, 2014) e, uma vez que esta podia ser acoplada a pilões de ferro, consequentemente garantia uma trituração em fragmentos mais finos e em menor tempo.

A inserção de pilões de ferro na cadeia produtiva do setor ervateiro reflete a introdução desse paradigma tecnológico no território nacional. De fato, o ferro teve importância crucial na Europa ao longo da Revolução Industrial, pois era insumo central na produção de bens de capital. Sua utilização - e também a do carvão e a do aço - como matéria-prima ocorreu especialmente no período de decadência da indústria 
têxtil e de subsequente ascensão de outros parques industriais, que foram desenvolvidos com capitais acumulados por industriais à procura de investimentos novos. Por conseguinte, o desenvolvimento de maquinarias feitas a partir desse metal proporcionou um aumento de produtividade nos mais variados setores, já que produziam com maior velocidade e força e, assim, permitiam ganhos com a produção de escala (Hobsbawm, 1986).

No caso do setor ervateiro, os engenhos hidráulicos com pilões de ferro, pouco a pouco, substituíram os soques manuais. Há uma variedade de relatos e documentos que contribuem com essa afirmação. Em 1836, por exemplo, a Câmara Municipal de Curitiba concedeu 21 lotes de terras com águas para instalação de engenhos destinados à produção de erva-mate (Ianni, 1988). Isso certamente contribuiu para que, em 1853, quando a Província do Paraná acabara de ser criada, o então presidente Zacarias de Goes e Vasconcelos, em seu primeiro ano como administrador, registrasse que os paranaenses se dedicavam economicamente (1) à pecuária; (2) à extração madeireira; (3) à extração, ao beneficiamento e à comercialização de erva-mate; e que, ao todo, havia 90 engenhos para atender a essa demanda (Relatório do presidente da Província do Paraná, 1854).

Exemplos similares dessa trajetória tecnológica também são encontrados para a província rio-grandense Em 1849, Abel Correa Câmara era o dono de um moinho d'água com 10 pilões de ferro para o beneficiamento de erva (Eckert, 2011). No relatório daVila de Cruz Alta, de 1853, enviado ao governo provincial, foi relatada a existência de 16 engenhos localizados no distrito de Campo Novo, todos funcionando plenamente e produzindo excelente erva, pronta para o consumo e a exportação (Bindé, 1968). O relato de um viajante italiano, exemplo da mesma época, registrou outro engenho em Campo Novo que possuía cerca de 10 a 12 pilões, impulsionados por enormes rodas d'águas, para realizar a moagem (Bindé, 1968). Já, no município de Rio Pardo, um viajante alemão discorreu sobre uma fábrica de erva-mate equipada com 46 pilões de puro ferro, que trituravam as folhas e os pequenos ramos com grande velocidade, possibilitando o beneficiamento de até 100 arrobas por dia (Avé-Lallemant, 1980a). Convém salientar que, de acordo com os registros encontrados, tais engenhos coexistiram com os monjolos, que provavelmente eram usados por produtores de menor porte. 
Figura 4 - Segunda fase da cadeia produtiva de erva-mate no ciclo dos engenhos hidráulicos

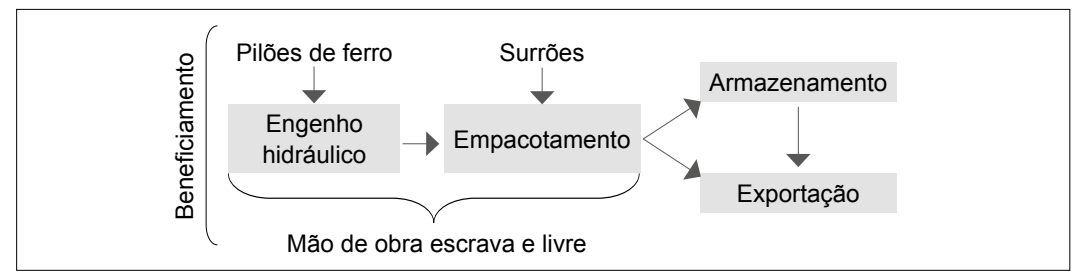

A presença dos monjolos, entretanto, não reduz o impacto decorrente da implementação de engenhos com pilões de ferro nesse período (1820-1870).Além disso, a despeito das imprecisões inerentes a qualquer registro de época, os relatos e documentos vistos há pouco parecem descrições entusiasmadas com essa tecnologia, indicando que ela se difundiu nas áreas produtoras de erva-mate e propiciou um significativo melhoramento desse setor. Isso porque os engenhos com pilões de ferro, como os próprios relatos indicam, tornaram mais eficiente a trituração de erva cancheada, que, após esse processamento adicional, ganhava a condição de erva beneficiada. Por fim, esta era acondicionada em surrões e transportada para armazéns, onde ficava estocada antes de ser destinada ao mercado interno ou externo.A Figura 4 ilustra essa fase de beneficiamento nos engenhos hidráulicos.

Nesse primeiro ciclo da cadeia produtiva de erva-mate (Figuras 3 e 4), consideram-se como imprescindíveis não apenas as modificações que ocorrem no cancheamento (a troca do carijo pelo barbaquá), mas também a substituição da trituração manual (soque) pela trituração exercida através de força hidráulica, principalmente a realizada em engenhos com pilões de ferro. Essas transformações decorrentes de inovações no processo produtivo viabilizaram uma produção em maior escala, o que indica uma maior competitividade, ocasionando um expressivo crescimento nas exportações de erva-mate durante esse período, evidenciado pelo gráfico da Figura 5, que apresenta a curva do volume de exportação nacional de erva-mate, em milhares de toneladas, para os anos de 1834 a 1870.

Esse gráfico sugere que os grandes ervateiros (donos de engenhos), por deterem os meios de produção responsáveis por agregar valor à erva-mate, aumentaram substancialmente os seus lucros. Em contrapartida, os extratores de erva-mate, geralmente pobres, não dispunham de con- 


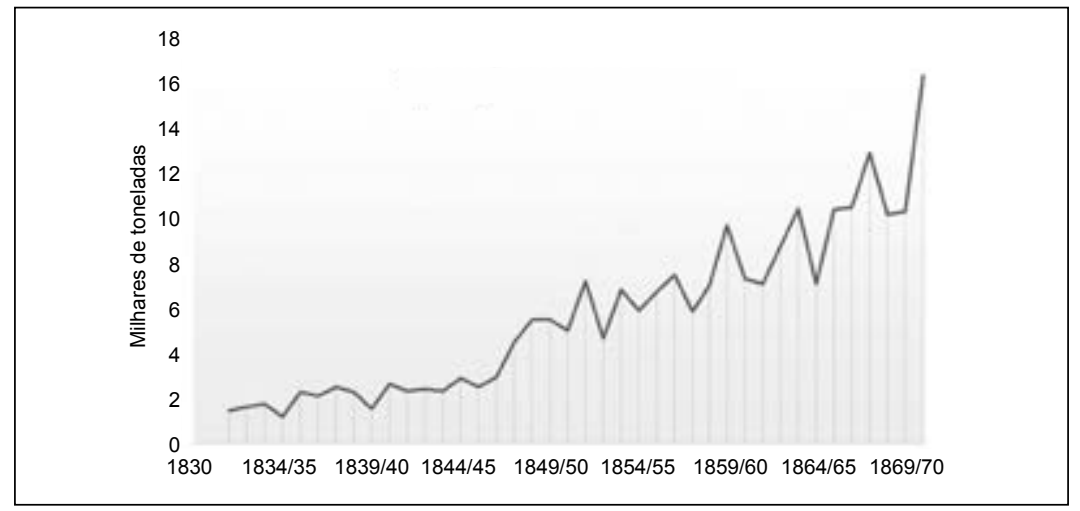

Fonte: IBGE (1990).

dições financeiras para adquirir as tecnologias emergentes e, talvez por isso mesmo, extraíam e repassavam a erva cancheada para os grandes ervateiros ou vendiam a sua força de trabalho para eles. Como exemplo do primeiro caso, na Província de Santa Catarina, de acordo com um registro de 1858, alguns homens (referenciados no documento como pequenos ervateiros) colhiam as folhas e as ramas do mate, realizavam o processo de cancheamento e, em seguida, enviavam essa erva para os engenhos maiores, onde era mais bem triturada e transformada em um pó mais fino (Avé-Lallemant, 1980b). Como exemplo do segundo caso, um ervateiro que morava na Província do Rio Grande do Sul, processado pela Justiça por fazer erva-mate sem licença, admitiu para o fiscal (encarregado de controlar o extrativismo) que as pessoas autuadas eram seus funcionários assalariados (Zarth, 1997). Além desses dois casos, também havia grupos de pequenos ervateiros que optavam pelo trabalho coletivo. Eles se reuniam entre dois a três trabalhadores para executar as tarefas e, após o período de colheita e produção, com a venda de erva-mate ao final, dividiam os lucros obtidos (Silveira, 1979).

Essas três situações indicam que existiam diferenças quanto ao emprego da mão de obra utilizada no setor ervateiro, inclusive algumas delas provinciais, como será visto na sequência. $\mathrm{Na}$ província paranaense, os barões do mate utilizaram um significativo contingente de trabalhadores cativos em todas as etapas da produção de erva-mate. Somente próximo ao final do período imperial que os escravos foram sendo substituídos 
por trabalhadores livres e pobres (Pena, 1999).A Província do Rio Grande do Sul, por sua vez, também fez uso do trabalhador cativo em todas as etapas de produção. Entretanto, nessa província, a grande massa coletora e produtora de erva-mate foram, principalmente, os trabalhadores livres e pobres, que utilizavam o trabalho nos ervais como forma de sobrevivência (Rosa, 2015). Já os ervais de Santa Catarina foram explorados pela população local pobre e livre e também por grandes ervateiros paranaenses, o que gerou conflitos pela posse do território e o direito de explorar os ervais públicos da província (Mafra, 2008).

Por fim, é importante ressaltar que as transformações ocorridas na cadeia produtiva de erva-mate promoveram alterações tanto nas condições técnicas quanto nas condições de mercado. De acordo com a teoria da "estrutura-conduta-desempenho" de Possas, é possível compreender que a inovação implantada no processo de produção durante o ciclo dos engenhos hidráulicos propiciou ganhos decorrentes das economias de produção em escala. Além disso, embora tais inserções mecânicas corroborassem a produção de erva com maior eficiência, elas também começaram a impor barreiras à entrada de concorrentes que não dispunham de capitais para investimento, de modo que os grandes produtores dessa mercadoria acumulassem vantagens competitivas diante dos pequenos produtores. Todavia, as alterações nas condições de mercado, explicadas por variáveis exógenas, como foi possível constatar no aumento do volume de exportações, também contribuíram para o crescimento desse setor. Essas transformações são reforçadas com as alterações implementadas na fase dos engenhos a vapor, apresentadas a seguir.

\section{Segundo ciclo: engenhos a vapor}

O fim do século XIX testemunhou um período de intensa mecanização da indústria ervateira: a novidade foi o advento de máquinas a vapor e, por conseguinte, a gradual substituição dos moinhos hidráulicos por engenhos que incorporavam essa nova tecnologia. Como consequência disso, o processo de produção de erva-mate se distanciou ainda mais do que fora a preparação artesanal realizada no início dos Oitocentos. Com relação à cadeia produtiva, entretanto, vale ressaltar que as 
etapas de abertura do acampamento e de colheita se mantiveram praticamente inalteradas e, portanto, dependentes do trabalho manual. As demais etapas sofreram alterações significativas, configurando, de certo modo, os primeiros protótipos para a moderna indústria ervateira que se estabeleceria ao longo do século XX.

Nesse segundo ciclo de produção, uma fornalha gerava o calor necessário para manter todos os maquinários ativos e, por isso, o produto não ficava mais exposto diretamente à fumaça, o que também contribuía para tornar o seu sabor mais agradável. Especificamente, o sapeco, outrora manual, passou a ser realizado por um "sapecador" mecânico, uma espécie de cilindro oco e rotativo (em torno do eixo axial) com cerca de $6 \mathrm{~m}$ de comprimento e $2 \mathrm{~m}$ de diâmetro, dentro do qual eram postas as folhas e as ramas do mate para secar em ar quente, a uma temperatura de $250{ }^{\circ} \mathrm{C}$, durante 30 a 40 segundos (Linhares, 1969). Tal dispositivo podia ser abastecido manualmente ou por meio de "esteiras transportadoras”. Convém observar que esse sapeco mecanizado, embora mantivesse a mesma denominação do procedimento manual de secagem presente desde o período de produção artesanal, substituiu inteiramente o sapeco manual e o barbaquá, que deixaram de existir com a finalidade de elevar as produções de escala.

$\mathrm{Na}$ sequência, a ramagem sapecada passava pelo primeiro processo de trituração em um outro tipo de estrutura cilíndrica e oca, o cancheador, que era o moedor mecânico. Seu interior era composto por saliências longitudinais e por duas molas em espiral presas a um eixo central. Ambas tinham a função de agitar e comprimir as folhas e as ramas oriundas do sapeco, fragmentando-as. Como última etapa, estas seguiam para um separador mecânico rotativo - uma espécie de peneira - que servia para a remoção de resíduos indesejáveis, como os pedaços de paus e as folhas que não foram trituradas adequadamente. Ao final desse fabrico, obtinha-se então a erva cancheada, conforme pode ser observado no diagrama da Figura 6.

Após cancheada, a erva passava novamente por um processo de trituração com o uso de pilões movidos por engenho a vapor, com o objetivo de transformá-la em um produto mais refinado. Na sequência, essa erva triturada seguia para o peneiramento em outro separador mecânico, no qual ela passava por um jogo de peneiras vibratórias onde ocorria uma separação por tamanho: palitos, goma (pó) e frações das folhas com 
Figura 6 - Primeira fase da cadeia produtiva de erva-mate no ciclo dos engenhos a vapor

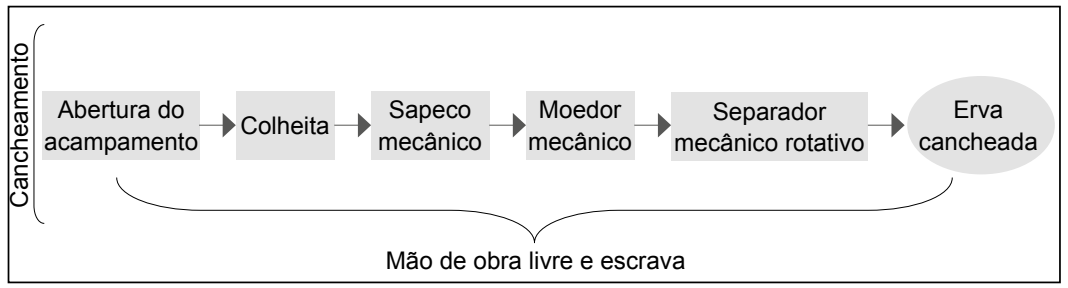

variados tamanhos (Maccari, 2005). Depois de passar por esse estágio, a erva era novamente secada, em um maquinário denominado torrador mecânico. Tal procedimento tinha como objetivo retirar a umidade ainda existente no produto. Por último, a erva ainda passava pelos misturadores, que tinham como objetivo misturar diferentes proporções da goma e dos palitos para compor ao menos dois tipos de erva-mate: a moída grossa e a moída fina. Após a mistura, o produto ganhava um aspecto mais uniforme que possibilitava o seu aproveitamento para tomar várias cuias, sem perder o sabor da bebida. Caso distinto do que acontecia, por exemplo, em 1822, quando Saint-Hilaire registrou que, após recolocar água dez vezes no chimarrão, era necessário pôr erva nova na cuia (Saint-Hilaire, 2002).

Pronta para o consumo, a erva beneficiada prosseguia para o empacotamento, etapa que também apresentou melhoramentos com a introdução do uso de barricas - fabricadas de pinho (tipo de madeira) e consideradas mais higiênicas e apresentáveis do que os antigos surrões. A difusão da barrica se deu com a invenção de uma prensa para embutir tampos, o que resolveu os antigos problemas mecânicos associados à sua vedação. Embora com diversos tamanhos, as barricas usuais armazenavam $75 \mathrm{~kg}$ do produto (Linhares, 1969).

Além disso, os ervateiros começaram a utilizar rótulos coloridos para identificar o tipo de erva (cancheada ou beneficiada) e o engenho produtor (Boguszewski, 2007) - mudanças que exemplificam algumas estratégias de inovação tomadas para atender a mercados mais exigentes. Resumindo todo o processo, conforme pode ser observado nos diagramas das Figuras 6 e 7, todas essas invenções (os secadores, os separadores, os trituradores, o misturador e o compressor) fizeram parte da maquinaria que, impulsionadas pelo engenho a vapor, constituíram a indústria 
de beneficiamento desse período, denominada popularmente de engenho de erva-mate, cujas instalações eram normalmente de alvenaria e assoalho (Martins, 1926).

Figura 7 - Segunda fase da cadeia produtiva de erva-mate no ciclo dos engenhos a vapor

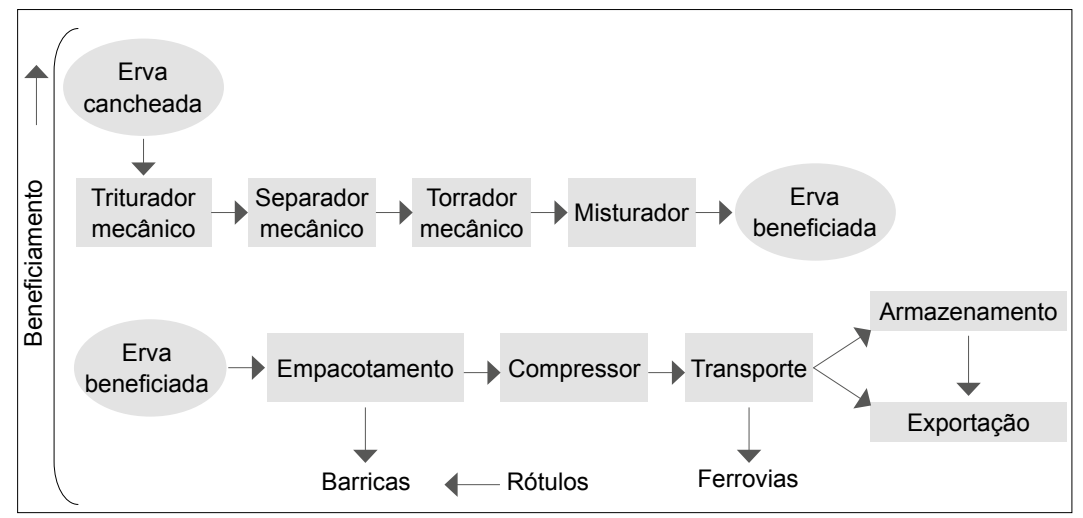

Por fim, ressalta-se que, apesar de todas as inovações desse segundo ciclo indubitavelmente terem transformado o setor ervateiro ao agregar melhoramentos tecnológicos nas diferentes etapas de produção, boa parte delas não foram criadas propriamente no Brasil. As tecnologias, em geral, eram copiadas de países centrais, fato este que reforça a concepção de imitação tecnológica adotada em países periféricos. O processo industrial da Europa, mais precisamente o da Inglaterra possibilitou que ao menos uma parcela dos desdobramentos técnico-científicos correntes adentrasse o Império brasileiro e, com isso, influenciasse as estruturas sociais e econômicas da nação.

O setor ervateiro, tal como os outros ramos da economia, beneficiou-se desse fato e, de certa forma, também se transformou a partir dos paradigmas industriais vigentes. Nessa época, o governo imperial enviou à Inglaterra e à Alemanha o engenheiro Francisco Camargo Pinto, que, após seu retorno, pôs em prática os conhecimentos aprendidos para liderar a construção de engenhos a vapor e outros equipamentos destinados a integrar a cadeia produtiva de erva-mate. Evidências disso estão apresentadas no Quadro 1, que reúne as principais patentes relacionadas às implementações tecnológicas propostas por Camargo Pinto após a 
sua viagem. Os maquinários e aparelhos referenciados nessas patentes, cujas validades duraram por dez anos, foram fabricados em Curitiba e no Rio de Janeiro e, posteriormente, enviados para engenhos do Paraná e de Santa Catarina, locais em que o próprio concessionário possuía alguns desses estabelecimentos produtores.

\begin{tabular}{|l|l|l|}
\hline \multicolumn{3}{|l|}{ Quadro 1 - Patentes do setor ervateiro concedidas a Francisco Camargo Pinto } \\
\hline Decreto N. & \multicolumn{1}{|c|}{ DAtA } & \multicolumn{1}{c|}{ PAtente } \\
\hline 7.180 & 1o de março de 1879 & Compressor de erva-mate \\
\hline 7.324 & 5 de julho de 1879 & Peneira ou separador mecânico \\
\hline 7.888 & 9 de novembro de 1880 & Máquina de moer mate \\
\hline 7.889 & 9 de novembro de 1880 & $\begin{array}{l}\text { Sistema de colher e preparar mate por meio de } \\
\text { aparelhos }\end{array}$ \\
\hline 8.417 & 11 de fevereiro de 1882 & $\begin{array}{l}\text { Sistema de colher e preparar mate por meio de } \\
\text { aparelhos }\end{array}$ \\
\hline
\end{tabular}

Fonte: O Auxiliador da Industria Nacional (1884).

\section{Transformações no setor ervateiro durante a segunda metade dos Oitocentos}

A partir da segunda metade do século XIX, ocorreram transformações sociais e econômicas que modificaram as estruturas sociais. Dentre estas está, por exemplo, a sanção da Lei Eusébio de Queirós em 4 de setembro de 1850 , que colocava fim ao tráfico negreiro e, com isso, engendrava transformações nas esferas socioeconômicas. A proibição do tráfico, por si só, tornou imprescindível a discussão da transição do trabalho escravo para o assalariado. No entanto, esse processo foi ocorrendo de forma lenta e gradual ao longo das décadas subsequentes. Nesse contexto, o setor ervateiro foi perdendo uma parcela da mão de obra escrava, que foi realocada para o setor cafeeiro (Rosa, 2015). Assim, no setor ervateiro e especialmente nas atividades dos engenhos a vapor, aos poucos, foram inseridos trabalhadores livres e assalariados que dividiam a labuta com os escravos (Pena, 1999).

Por conta disso, os engenhos de erva-mate começaram a apresentar, em média, sete empregados: um forneiro, que cuidava da torrefação; dois coadores, responsáveis por peneirar a matéria-prima; um piloeiro, que 
cuidava dos pilões; dois ensurradores, responsáveis pelo processo de empacotamento; e, por fim, o foguista maquinista, encarregado pela manutenção do fogo e por acionar o maquinismo produtor do vapor.Além da distinção funcional, a especialização da mão de obra incorria em diferentes responsabilidades e, portanto, remunerações: o foguista maquinista recebia em média $100 \$ 000$ por mês, enquanto os demais trabalhadores ganhavam equivalente a $2 \$ 000$ por dia de trabalho; já os ensurradores recebiam por surrão ou barrica preenchida (Westphalen, 1998). Uma das justificativas para o maior salário do foguista se dava porque o engenho a vapor apresentava alguns riscos iminentes. $\mathrm{O}$ mais comum deles eram os incêndios. Um exemplo disso ocorreu no engenho do major Bento Florencio Munhoz, em abril de 1879, que reduziu a propriedade a ruínas, causando um prejuízo calculado entre 10 a 12 contos de réis (Relatório de Província, 1879). Outro exemplo é o incêndio que aconteceu, em 1905, no Engenho São Lourenço, em Curitiba. Durante a investigação, os peritos observaram que o engenho era bem construído, de alvenaria, tinha assoalho com barrotes de imbuia e concluíram que o incêndio fora, possivelmente, causado por fagulhas da máquina (Gerhardt, 2013). Por fim, todos esses fragmentos históricos são apenas mostras de como a indústria ervateira teve que se adaptar com situações novas advindas das transformações que ocorreram nesse meio século.

Paulatinamente também houve um acúmulo de capitais decorrentes dos ganhos do crescimento do setor. Parte disso foi reinvestida na construção de um sistema de escoamento ferroviário na Província do Paraná. Afinal, a partir da segunda metade do XIX, as ferrovias revolucionaram os meios de transporte, e a proliferação delas foi o reflexo do processo de industrialização, primeiramente em território britânico e, em seguida, nas demais nações do mundo, o que permitiu a transnacionalização de capitais, a interconexão de mercados outrora distantes e a ocupação de outros territórios. Motivadas por essas circunstâncias, as ferrovias foram construídas em várias províncias do Império. Em relação ao Paraná, as estradas de ferro foram instaladas no decênio de 1880 e contribuíram à prestação de serviços de locomoção tanto de passageiros quanto de mercadorias, o que exerceu profunda influência sobre a expansão comercial e industrial dos seus dois principais setores econômicos: o ervateiro e o madeireiro. Essas novas vias de transporte também contribuíram para a 
integração e a exploração dos ervais do planalto curitibano, que, com o passar do tempo, superou a produção de Morretes e Antônia - considerados, até então, os principais polos produtores. Essa migração, por consequência, facilitou o escoamento do produto, dinamizou a economia regional (Kroetz, 1985) e possibilitou que a erva-mate paranaense mantivesse o seu espaço no mercado internacional.

No caso da Província do Rio Grande do Sul, a economia ervateira adentrou os últimos anos do Império com uma forte desaceleração econômica, especialmente em relação ao mercado externo. Essa crise estava atrelada à intensa participação dessa província nos quase cinco anos da Guerra do Paraguai, que resultou em instabilidade econômica e vertiginosa queda de exportação dos setores tradicionais, como o charque e a erva-mate. Isso ocorreu porque o setor ervateiro, durante o período da guerra, não utilizou parte do capital acumulado para reinvestir no aparelho produtivo. As principais inovações desse setor foram realizadas nos finais de 1840-1850 e, depois disso, embora essa tecnologia atendesse às demandas do mercado nos primeiros decênios de sua instauração, não ocorreram outros melhoramentos significativos até o fim do Império. Essa defasagem no aparelho produtivo fatalmente contribuiu com o enfraquecimento do setor a longo prazo. Além disso, é notável que a conjuntura internacional deu fôlego ao setor durante a Guerra do Paraguai, período em que o volume de exportação foi em média 20 mil sacas a mais que os anos antecedentes (Rosa, 2015). Contudo, após a beligerância e posterior restabelecimento do Paraná, o setor ervateiro rio-grandense se viu em meio à crise, pois não conseguiu competir. Conforme abordado, Schumpeter (1984) colocou a inovação como principal estratégia ativa adotada pelos mais variados ramos produtivos que têm como objetivo acumular vantagens competitivas diante dos concorrentes. Sem inovar, essa província perdeu capacidade de competir com seu principal concorrente.

As inovações introduzidas no processo produtivo pelo setor ervateiro paranaense propiciaram ganhos decorrentes da produção em larga escala e da melhoria da qualidade da mercadoria, com a implantação do sapeco mecanizado e do empacotamento nas barricas, por exemplo. Ainda que isso denote um acúmulo de vantagens competitivas decorrentes das condições técnicas criadas, o referencial de análise "estrutura-conduta-desempenho" de Possas permite comparar as províncias do Rio do Grande 
do Sul e do Paraná com relação às condições de mercado. As condições técnicas, que englobam as variáveis endógenas, relacionadas às decisões de investimento e às estratégias adotadas pela inovação, somadas às condições de mercado, que englobam as variáveis exógenas, conduzem a uma estrutura mais favorável à Província do Paraná. Embora ambas as províncias tenham se beneficiado da expansão da demanda no período da Guerra do Paraguai, o desenvolvimento do transporte ferroviário na região paranaense contribuiu consideravelmente para a economia do mate, que obteve ganhos também na fase de distribuição. Desse modo, a estrutura favorável influenciou a conduta dos ervateiros que, incentivados, realizaram mais investimentos em inovação, consolidando, por sua vez, o melhor desempenho do setor na região do Paraná.Além disso, esse melhor desempenho decorrente da conduta e da estrutura consolidou uma relação direta na criação de barreiras à entrada de novos concorrentes. Tais barreiras surgem tanto entre as regiões quanto entre ervateiros da mesma região, dado o distanciamento entre os pequenos produtores e os barões do mate que acumulavam vantagens. A diferença no desempenho das províncias pode ser observada pela comparação quantitativa dos índices de exportação. O gráfico da Figura 8 apresenta, em milhares de toneladas, a quantidade de erva-mate exportada pelo Rio Grande do Sul e pelo Paraná, no período de 1856 a 1889.

Figura 8 - Exportação de erva-mate das províncias paranaense` e rio-grandense ${ }^{\star \star}$

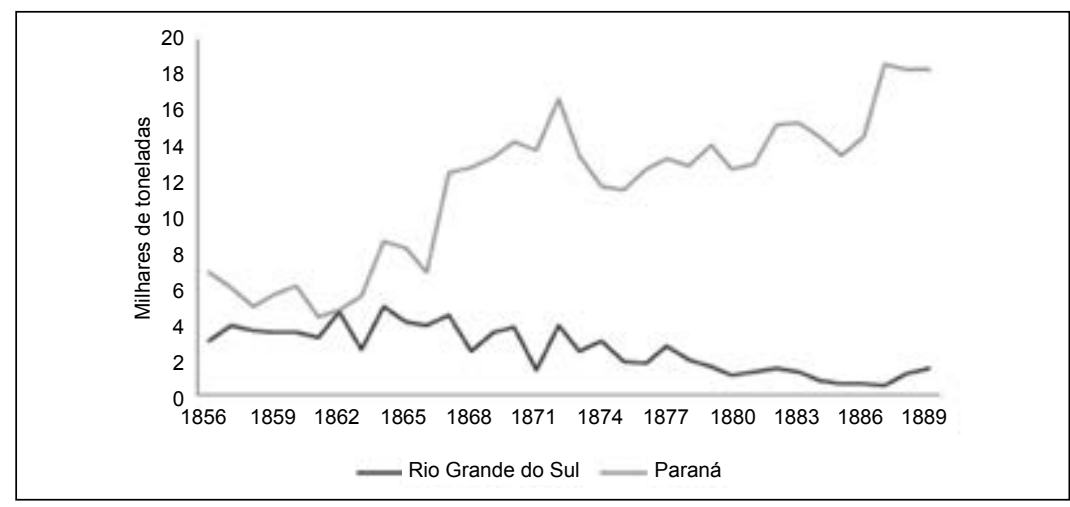

Fonte: ${ }^{\star}$ Kroetz (1985), ${ }^{\star \star ~ R e v i s t a ~ d o ~ A r q u i v o ~ P u ́ b l i c o ~ d o ~ R i o ~ G r a n d e ~ d o ~ S u l ~(1922) . ~}$

Ademais, com relação à região de Santa Catarina, sabe-se que o setor 
ervateiro se desenvolveu principalmente nas regiões do planalto e ao sul do vale do rio Negro, a partir da migração de produtores paranaenses que utilizavam a mão de obra local. Com o tempo, a população e a economia catarinense também foram se beneficiando e se desenvolvendo em torno da economia do mate. Ao longo dos Oitocentos, surgiram conflitos entre catarinenses e paranaenses pela posse de áreas de ervais na região do Contestado. Esses conflitos influenciaram, de certa forma, na eclosão da Guerra do Contestado. Mais tarde, final dos Oitocentos, novos polos econômicos surgiram diante do desenvolvimento do setor, abrangendo as cidades hoje denominadas Joinville e Mafra. Nesse cenário, a criação da Companhia Industrial Catarinense teve um papel crucial na região, além de revelar a importância da participação pública no desenvolvimento econômico, já que a empresa configurava uma estatal que exercia o monopólio das atividades de extração e de comércio da erva. Essa companhia surgiu devido à atuação da Província de Santa Catarina, que, na tentativa de superar os empecilhos econômicos colocados pela Província do Paraná, buscou auxílio e conseguiu incentivos fiscais com o governo imperial (Mafra, 2008). Isso reforça a hipótese apresentada pela qual a busca por vantagens competitivas focada na inovação pode introduzir novas formas de organizações empresariais, que atingem tanto os setores privados quanto públicos.

Assim, o fim do século XIX testemunhou um período transformação da indústria ervateira, especialmente nas últimas décadas dos Oitocentos. Com o advento das novas máquinas, ocorreu a gradual substituição dos engenhos hidráulicos por engenhos a vapor. Essa mudança refletiu grandes melhoramentos em todos os demais processos de beneficiamento do mate, bem como aperfeiçoou todo o maquinário (Martins, 1926), revolucionou a forma de produção, rompeu com o processo artesanal e estabeleceu técnicas mecanizadas que impactam esse setor até a contemporaneidade.

\section{Conclusão}

O estudo da trajetória do setor ervateiro oitocentista permitiu observar a relevância das estratégias adotadas e das interações intra e intersetoriais, sendo possível concluir que a inovação, ainda que subordinada 
aos paradigmas tecnológicos externos, foi crucial à evolução desse ramo. Grande parte das mudanças observadas no mercado de erva-mate durante o século XIX foram atribuídas às transformações na cadeia produtiva do setor. Tais modificações não ocorreram de forma simultânea nas três regiões produtoras analisadas, mas constituíram períodos que, apesar de serem vivenciados em momentos distintos, consolidaram técnicas de produção e de padrões tecnológicos comuns. Além disso, a diferença de tempo na incorporação de uma tecnologia de uma região para outra angariou uma série de vantagens competitivas, que colocaram em cena uma província e subjugaram outra, mostrando o conjunto de táticas que envolvem os processos de escolha e implementação de uma inovação e de novas formas de comercialização. Essas transformações nas estruturas desnudam as diferenças de tempo e de espaço da trajetória do setor ervateiro.

Além disso, este trabalho procurou inovar na interpretação acerca da trajetória do setor ervateiro oitocentista. De modo geral, manteve-se a periodização temporal delimitada por Linhares; no entanto, foram consideradas como marcos de rupturas e emergência de uma nova fase elementos distintos daqueles eleitos pelo autor. Essa mudança na visualização, apresentada neste trabalho, se deve principalmente ao embasamento da economia do mate em teorias microeconômicas mais consolidadas, que ressaltam a importância da inovação e da introdução de processos e de produtos. Em relação à fase artesanal, não ocorreram mudanças significativas no modo de interpretar o processo produtivo de erva-mate. As diferenças interpretativas ocorreram principalmente em relação à fase dos engenhos hidráulicos e à fase dos engenhos a vapor. Em relação às primeiras mudanças, entende-se que a introdução do ferro foi a implementação tecnológica mais relevante devido à resistência desse material, que possibilitou uma melhor trituração da matéria-prima em menor tempo. A introdução dos pilões de ferro nos engenhos hidráulicos corroborou a hipótese de que nesse período os reflexos da industrialização moderna, especialmente a inglesa, também influenciaram a produção ervateira na substituição de processos manuais por maquinarias. Já em relação à fase seguinte, a implementação dos engenhos a vapor e das ferrovias foram analisadas dentro de um contexto mais geral, no qual a economia ervateira também estava inserida. Por isso, esse processo foi compreendido dentro da expansão do imperialismo 
inglês concomitante com teorias microeconômicas que analisaram os resultados desses processos de inovação e das estruturas do setor, para as sociedades inseridas nesses contextos históricos.

Por fim, a avaliação quantitativa das exportações de erva-mate vislumbrou a superioridade da produção paranaense, o que reforçou a importância das estratégias adotadas por produtores dessa região. Nesse sentido, destacou-se a adoção de práticas ativas (inovações de métodos) e passivas (patentes), para se sobressair à concorrência. Por outro lado, parcerias com o desenvolvimento de infraestrutura, por meio de ferrovias, bem como outras alianças com o governo imperial - como o caso do monopólio em Santa Catarina -, contribuíram para desenvolver a estrutura do setor ervateiro, o que também influenciou na conduta e no desempenho dos produtores de cada região, além de reiterar o entrelaçamento entre setores público e privado como fomento ao crescimento econômico regional.

\section{Referências bibliográficas}

ANDRADE, F. C. D. A presença dos moinhos hidráulicos no Brasil. Anais do Museu Paulista. São Paulo, v. 23, n. 1, p. 133-193, 2014.

AVÉ-LALLEMANT, R. Viagem pela Província do Rio Grande do Sul. Belo Horizonte: Itatiaia, 1980a.

AVÉ-LALLEMANT, R. Viagens pelas províncias de Santa Catarina, Paraná e São Paulo (1858). São Paulo: Universidade de São Paulo, 1980b.

BANDEIRA do Paraná. Wikipédia, a enciclopédia livre. Disponível em $<$ https://pt.wikipedia.org/wiki/Bandeira_do_Paraná>. Acesso em 12 jan. 2016.

BESCHOREN, M. Impressões de viagem na Província do Rio Grande do Sul. Porto Alegre: Martins Livreiro, 1989.

BINDÉ,W. Campo Novo: apontamentos para sua história. Santo Ângelo: Gráfica Santo Ângelo, 1968.

BOGUSZEWSKI,J.H. Uma história cultural da erva-mate: o alimento e suas representações. Curitiba: Universidade Federal do Paraná, 2007 (Dissertação de Mestrado).

BRAUDEL, F. Civilização material, economia e capitalismo, séculos XV-XVIII.V. 1:As estruturas do cotidiano. [S.1.]: Martins Fontes, 1995.

CARVALHO, P. E. R. Espécies arbóreas brasileiras. Curitiba: EMBRAPA Informações Tecnológicas/EMBRAPA Florestas, 2003.

COMEX. Ministério da Indústria, Comércio Exterior e Serviços. Banco de dados, 2015. Disponível em $<$ http://www.mdic.gov.br/index.php/comercio-exterior>. Acesso em 2016. 
COUTY, L. Le mate et les conserves de viande: rapport a son excellence monsieur le ministre de l'Agriculture e du Commerce - sur sa mission dons les provinces du $\mathrm{Pa}-$ rana, Rio Grande et les etats du Sud. Rio de Janeiro: Typ. A Republica, 1880.

DANTAS,A.; KERTANETZKY,J.; PROCHNIK,V. Empresa, indústria e mercados. In: KUPFER, D.; HANSENCLEVER, L. Economia industrial: fundamentos teóricos e práticas no Brasil. 2. ed. Rio de Janeiro: Campus, 2002.

DORATIOTO, F. F. M. Maldita guerra: nova história da Guerra do Paraguai.São Paulo: Companhia das Letras, 2002.

DOSI, G. Mudança técnica e transformação industrial - a teoria e uma aplicação à indústria dos semicondutores. 2. ed. Campinas: Editora da UNICAMP, 2006.

ECKERT,J.P. O povo dos ervais - entre o extrativismo e a colonização (Santa Cruz, 18501890). São Leopoldo: UNISINOS, 2011 (Dissertação de Mestrado).

FURTADO, C. Formação econômica do Brasil. Rio de Janeiro: Fundo de Cultura, 1959.

GERHARDT, M. História ambiental da erva-mate. Florianópolis: Universidade Federal de Santa Catarina, 2013 (Dissertação de Mestrado).

HOBSBAWM, E. Da Revolução Industrial inglesa ao imperialismo. Rio de Janeiro: Forense, 1986.

HOSZCZARUK.J.T.V. Importância econômica da produção de erva-mate (Ilex paraguariensis St. Hil.) para o município de Machadinho-RS. Curitiba: Universidade Federal do Paraná, 2015 (Monografia, Ciências Agrárias, trabalho de final de curso em Gestão Florestal).

IANNI, O. As metamorfoses do escravo: apogeu e crise da escravatura no Brasil meridional. 2. ed. São Paulo: HUCITEC, 1988.

IBGE. Estatísticas históricas do Brasil: séries econômicas e sociais de 1550 a 1888.V.3. 2. ed. Rio de Janeiro: IBGE, 1990.

IBGE. Produção da extração vegetal e da silvicultura. [S.1.]: IBGE, 2013.

ISABELLE, A. Viagem ao rio da Prata e ao Rio Grande do Sul.V. 1. Rio de Janeiro: Z. Valverde, 1949.

KROETZ, L. R. As estradas de ferro no Paraná (1888-1940). São Paulo: USP, 1985 (Tese de Doutorado).

LIMA, M. D. R. D. S. Formas de energia no Brasil - século XIX. Campinas: Instituto de Economia, UNICAMP, 1983 (Dissertação de Mestrado).

LINHARES, T. História econômica do mate. Rio de Janeiro: J. Olympio, 1969.

MACCARI,A. Análise do pré-processamento da erva-mate para chimarrão. Campinas: UNICAMP, 2005 (Tese de Doutorado).

MAFRA, A. D. Aconteceu nos ervais: a disputa territorial entre Paraná e Santa Catarina pela exploração da erva-mate - região sul do vale do rio Negro. Canoinhas: Universidade do Contestado, 2008 (Dissertação de Mestrado).

MAGNUS, D. M. P. Semeando iras rumo ao progresso: ordenamento jurídico e econômico da sociedade paranaense (1829-1889). Curitiba: UFPR, 1996.

MARTINS, R. Ilex-mate: chá sul-americano. Curitiba: Gráfica Paranaense, 1926.

O AUXILIADOR da Industria Nacional. Periodico da Sociedade Auxiliadora da Industria Nacional. Rio de Janeiro, LIL, n. 1, 1884. 
OLIVEIRA, Y. M. M. D.; ROTTA, E. Área de distribuição natual de erva-mate (IIex paraguariensis St. Hill.). ANAIS DO V SEMINÁRIO SOBRE ATUALIDADES E PERSPECTIVAS FLORESTAIS. Curitiba: [s.ed.], 1883.

OLIVEIRA, Y. M. M.; ROTTA, E. Áreas de distribuição natual da erva-mate. X SEMINÁRIO SOBRE ATUALIDADES E PERSPECTIVAS FLORESTAIS: SIVICULTURA DA ERVA-MATE (ILEX PARAGUARIENSIS ST. HILL.), 1985, Curitiba, CNPF, EMBRAPA.

PENA, S. O jogo da face: a astúcia escrava frente aos senhores e a lei na Curitiba provincial. Curitiba:Aos Quatro Ventos, 1999.

PEREIRA, M. R. Semeando iras rumo ao progresso: ordenamento jurídico e econômico da sociedade paranaense (1829-1889). Curitiba: Editora da UFPR, 1996.

PORTER, M. E. Estratégia competitiva: técnicas para análise de indústrias e da concorrência. Rio de Janeiro: Campus, 1986.

POSSAS, M. L. Estruturas de mercado em oligopólio. 2. ed. São Paulo: HUCITEC, 1990.

PRADO JÚNIOR, C. Formação do Brasil contemporâneo. São Paulo: Brasiliense, 1942.

RELATÓRIO de Província. Relatório apresentado á Assembléa Legislativa do Paraná no dia 4 de junho de 1879 pelo exmo presidente da província, o bacharel Manuel Pinto de Souza Dantas Filho. Curitiba:Typ. Perseverança, 1879.

RELATÓRIO do presidente da Província do Paraná. Relatório do presidente da província do Paraná, o conselheiro Zacarias de Góes eVasconcellos, na abertura da Assemblea Legislativa Provincial em 15 de julho de 1854. Curitiba:Typ. Paranaense, 1854.

REVISTA do Arquivo Público do Rio Grande do Sul. Porto Alegre, Oficina Gráfica da Escola de Engenharia de Porto Alegre, n. 8, 1922, v. 15, 16, 1924.

ROSA, L. A trajetória do setor ervateiro na Província do Rio Grande do Sul. Campinas: Instituto de Economia, UNICAMP, 2015 (Dissertação de Mestrado).

SAINT-HILAIRE, A. Viagem a Curitiba e Província de Santa Catarina. São Paulo: Editora da USP, 1978.

SAINT-HILAIRE,A.Viagem ao Rio Grande do Sul. Brasília: Conselho Editorial, 2002.

SANTOS, C. R. Vida material, vida econômica. Cutitiba: CEED, 2001.

SANTOS, R. M. O rascunho da nação: formação, auge e ruptura da economia colonial. Campinas: Instituto de Economia, UNICAMP, 1985 (Dissertação de Mestrado).

SCHUMPETER, J. A. Capitalismo, socialismo e democracia. Rio de Janeiro: Zahar, 1984.

SILVA, L. G. Concorrência sob condições oligopolísticas: contribuição das análises centradas em grau de atomização/concentração dos mercados. 2. ed. Campinas: IE, UNICAMP, 2010.

SILVA, L. O. Terras devolutas e latifúndio: efeitos da lei de 1850. Campinas: Editora da UNICAMP, 2008.

SILVEIRA, H.J.V. D. As missões orientais e seus antigos domínios. Porto Alegre: Erus, 1979. SILVEIRA, H.J.V. D. As missões orientais e seus antigos domínios. Porto Alegre: Erus, 1990.

SIMONSEN, R. C. História econômica do Brasil (1500-1820). 3. ed. São Paulo: Companhia das Letras, 1957.

SOARES, S. F. Notas estatísticas sobre a produção agrícola e carestias dos gêneros alimentícios no Império do Brasil.Rio de Janeiro: IPEA/INPES, 1977. 
UCHA, D. SINDIMATE - RS: 70 anos. Porto Alegre: Palomas, 2012.

VIEIRA, M.A. Análise de hidrocarbonetos policíclicos aromáticos (HPAs) nas etapas do processamento da erva-mate (Ilex paraguariensis) e caracterização química dos resíduos da trituração para o desenvolvimento de produto. Florianópolis: Universidade Federal de Santa Catarina, 2009 (Tese de Doutorado).

WESTPHALEN, C. M. Porto de Paranaguá: um sedutor. Curitiba: Secretaria de Estado de Cultura, 1998.

ZARTH, P. F. História agrária do planalto gaúcho (1850-1920). Ijuí: UNIJUÍ, 1997. 